MARIA CIEŚLA

Instytut Historii PAN, Warszawa

\title{
LICZEBNOŚĆ ŻYDÓW W WIELKIM KSIĘSTWIE LITEWSKIM W XVII W.
}

Jedno z podstawowych pytań, które stawia sobie historyk rozpoczynający badania nad żydowską diasporą w dawnej Rzeczypospolitej, dotyczy liczebności tej grupy. Odpowiedź na nie jest tylko pozornie prosta. W dotychczasowych badaniach, szczególnie tych dotyczących Wielkiego Księstwa Litewskiego (dalej WKsL), trudno znaleźć szczegółowe dane. Podkreśla się znaczenie żydowskiej ekspansji demograficznej dla rozwoju stosunków chrześcijańsko-żydowskich oraz jej wpływ na charakter kultury żydowskiej w Europie Środkowo-Wschodniej. Brak jednak danych liczbowych i nie wiadomo dokładnie, ilu Żydów mieszkało na terenie Rzeczypospolitej Polsko-Litewskiej oraz jakie były najważniejsze etapy rozwoju demograficznego diaspory ${ }^{1}$.

Główną przyczyną problemów w badaniach nad demografią żydowską jest brak odpowiednich źródeł. Dla epoki wczesnonowożytnej nie zachowały się żadne materiały statystyczne. Co więcej, nie dysponujemy nawet danymi fiskalnymi. Jedyny stały podatek opłacany przez Żydów, tak zwane pogłówne żydowskie, był zryczałtowany i nie zależał od faktycznej liczby ludności. Wysokość podatku była determinowana potrzebami skarbu państwowego ${ }^{2}$. Pierwszy ogólny spis Żydów - którego protokoły są doskonałym źródłem do badań demograficznych - przeprowadzono

${ }^{1}$ G. D. Hundert, Żydzi w Rzeczypospolitej Obojga Narodów w XVIII w. Genealogia nowoczesności, Warszawa 2007 (oryg. ang. 2004), s. 41.

${ }^{2}$ H. Wisner, Rzeczpospolita Wazów, t. 2: Wojsko Wielkiego Księstwa Litewskiego. Dyplo-

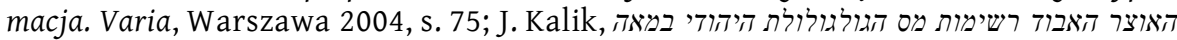
היח שבארהיון הצבה הפולנית [Utracony skarb. Spisy pogłównego żydowskiego z XVIII wieku znajdujące się w polskim archiwum wojskowym], „Zijon” 69, 2004, 3, s. 340. 
w latach $1764-1765^{3}$. Z tego też powodu jedynymi danymi liczbowymi, które podawane są w ogólnych opracowaniach, są właśnie wyniki spisu żydowskiego z 1765 r. Przyjmuje się, że w roku tym mieszkało na terenie WKsL około 157 tys. Żydów ${ }^{4}$.

Prezentowane rozważania są próbą odpowiedzenia na pytanie o liczebność diaspory żydowskiej w WKsL w XVII w. Zarówno wybór obszaru moich zainteresowań, jak i zakres chronologiczny nie są przypadkowe. Nieco odmienny rozwój społeczny oraz gospodarczy ziem WKsL spowodował, że Żydzi litewscy tworzyli w ramach żydowskiej diaspory w dawnej Rzeczypospolitej odrębną grupę ${ }^{5}$. Dlatego też niezbędne jest oddzielne prześledzenie jej rozwoju demograficznego. Wybór XVII w. zdeterminował fakt, że w dotychczasowych badaniach jest to okres najbardziej zaniedbany.Jedyne informacje opublikowane dotychczas pochodzą z prac poświęconych historii lokalnej - dotyczą tylko kilku obszarów WKsL ${ }^{6}$. Metoda określania wielkości litewskiej diaspory żydowskiej poprzez porównanie z Koroną, stosowana w przedwojennej historiografii żydowskiej, przede wszystkim przez Ignacego Schipera, wydaje się bardzo mało wiarygodna. $U$ jej podstawy leży bowiem wątpliwe założenie, że wysokość pogłównego żydowskiego była zależna od liczby ludności. W nowszych badaniach dowiedziono, że

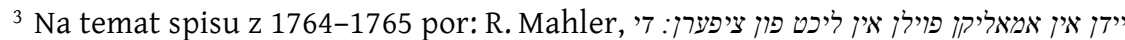
[Żydzi w dawnej Polsce w świetle cyfr. Struktura demograficzna i socjalno-ekonomiczna Żydów w Koronie w XVIII wieku], Warszawa 1958; idem, Żydzi w dawnej Polsce w świetle liczb, „Przeszłość Demograficzna Polski. Materiały i Studia” 1, 1967, s. 131-181; S. Stampfer, The 1764 Census of Polish Jewery, „Annual of Bar Ilan University Studies in Judaica and the Humanities" (Jerusalem), vol. 24-25, 1989, s. 41-59. Na temat spisu w Wielkim Księstwie Litewskim: S. Stampfer, The Census of 1764 Lithuanian Jewry And What It Can Teach Us, „Papers of Jewish Demography” 1993, s. 91-121. J. Šiaučiūnaitė-Verbickienè, The Jewish Living Space in the Grand Duchy of Lithuania: Tendencies and Ways of Formation, w: Jewish Space in Central and Eastern Europe. Day-to-Day History, red. eadem, L. Lempertienè, Newcastle upon Tyne 2007, s. 7-27; eadem, Žydai Lietuvos Didžiosios Kunigaikštystés visuomenéje aspektai, Vilnius 2009.

${ }^{4}$ R. Mahler, Żydzi w dawnej Polsce, s. 159.

${ }^{5} \mathrm{Na}$ temat odmienności społeczno-gospodarczych diaspory litewskiej por. M. Cieśla, Sharing a Commonwealth - Polish Jews or Lithuanian Jews, ,Gal-Ed” 24, 2015, s. 15-44.

${ }^{6}$ Por: G. Błaszczyk, Liczebność Żydów na Żmudzi w XVI-XVIII wieku, cz. 1, „Biuletyn Żydowskiego Instytutu Historycznego" (dalej: BŻIH) 1987, nr 141, s. 21-39; idem, Liczebność Żydów na Żmudzi w XVI-XVIII wieku, cz. 2, BŻIH 1988, nr 145/146, s. 23-29; I. Klausner, תולדות הקהל העברית בוילנה הלק רישון [Dzieje gminy żydowskiej w Wilnie], cz.1, Wilno 1938; M. Łowmiańska, Wilno przed najazdem moskiewskim 1655 roku, w: eadem, H. Łowmiański, Dwa doktoraty z Uniwersytetu Stefana Batorego w Wilnie, Poznań 2005, s. 151-329; M. Nadav, The Jews of Pinsk, 1506 to 1880, red. M.J. Mirsky, M. Rosman, Stanford, Calif. 2007 (oryg. hebr. 1973).
} 
kwota podatku, którą zbierano od Żydów, była zależna od sytuacji finansowej oraz potrzeb państwa, a nie od liczebności diaspory ${ }^{7}$.

Moim zamierzeniem jest pokazanie możliwości, jakie dają nie wykorzystywane dotychczas źródła skarbowe. Stan ich zachowania nie jest równomierny, pozwala jedynie na obliczenie ogólnej liczby Żydów litewskich w pierwszej połowie XVII w. Niestety nie dysponuję źródłami pokazującymi analogiczne dane dla drugiej połowy tegoż stulecia. Dlatego w drugiej części artykułu skoncentruję się przede wszystkim na opisaniu ogólnego rozwoju demograficznego na podstawie wybranych przykładów, postaram się także pokazać najważniejsze punkty zwrotne.

Próba określenia liczebności diaspory żydowskiej w WKsL w XVII w. oparta została na bardzo różnorodnym materiale źródłowym. Najważniejszą jego część tworzy litewska dokumentacja skarbowa, przechowywana w Litewskim Historycznym Archiwum Państwowym w Wilnie, a także pojedyncze dokumenty pochodzące $\mathrm{z}$ Warszawskiego Archiwum Radziwiłłowskiego (AGAD). Przede wszystkim wykorzystałam abjuratę dymów z 1650 r. ${ }^{8}$ Kolejne informacje czerpałam $\mathrm{z}$ abjurat pogłównego generalnego $\mathrm{z}$ lat siedemdziesiątych XVII w. Dane tutaj przedstawiane dotyczą wielu ośrodków, nie udało się jednak zgromadzić informacji dotyczących całego państwa9 Mniejszy walor mają abjuraty podymnego, gdyż jedynie wyjątkowo odnotowywano w nich oddzielnie liczbę Żydów ${ }^{10}$. Pomocniczo wykorzystane zostały także inwentarze dóbr prywatnych - ze względu na doskonały stan zachowania archiwum radziwiłłowskiego przeważają inwentarze dóbr należących do tego rodu. Dodatkowym źródłem stały się również protokoły posiedzeń Waadu litewskiego.

\section{Pierwsza połowa XVII w.}

Stan zachowania źródeł nie pozwala na pokazanie wiarygodnych danych dotyczących liczebności Żydów w WKsL w pierwszych latach XVII w. I. Schiper, stosując kontrowersyjną metodę porównawczą, przyjmował,

${ }^{7}$ I. Schiper, Rozwój ludności żydowskiej na ziemiach dawnej Rzeczypospolitej, w: Żydzi w Polsce Odrodzonej. Działalność społeczna, gospodarcza, oświatowa i kulturalna, red. idem, A. Tartakower, A. Haftka, t. 1, Warszawa 1932, s. 21-35; A. Filipczak-Kocur, Skarb litewski za pierwszych Wazów 1587-1648, Wrocław 1994, s. 39-40.

${ }^{8} \mathrm{Na}$ temat podatku podymnego, por: A. Filipczak-Kocur, Skarbowość Rzeczypospolitej 1587-1648. Projekty - Ustawy - Realizacja, Warszawa 2006, s. 53-58.

${ }^{9} \mathrm{Na}$ temat podymnego, ibidem, s. 65-66.

10 Por. Metryka Litewska. Rejestry podymnego Wielkiego Księstwa Litewskiego. Województwo wileńskie 1690 r., oprac. A. Rachuba, Warszawa 1989, s. 60-62. Jest to jeden z nielicznych rejestrów obejmujących osobny spis Żydów mieszkających w Wilnie. 
że pod koniec XVI w. w WKsL żyło około 27 tys. Żydów ${ }^{11}$. Z badań Saula Barona wynika, że w tym samym okresie funkcjonowało tam 20 gmin $^{12}$. Bardziej wiarygodne wydają się szacunki Sergieja Bierszadskiego (Sergej Aleksandrovič Beršadskij), który dla tego samego okresu szacował około 10-12 tys. Żydów ${ }^{13}$. Najnowsze badania Jurgity Šiaučiūnaité-Verbickienė wykazały, że w latach 1563-1566 żyło w WKsL około 14-15 tys. Żydów ${ }^{14}$. Przedstawiane tutaj liczby dotyczą obszaru WKsL sprzed 1569 r. - czyli obejmują również dość duże gminy wołyńskie, które w wyniku unii lubelskiej znalazły się w Koronie.

Jedyną bardziej szczegółową informacją dotyczącą żydowskiego osadnictwa na terenach WKsL w pierwszej połowie XVII w. jest uchwała Waadu z roku 1623 dzieląca obszary wpływu poszczególnych gmin, które funkcjonowały wtedy w WksL. W sumie w dokumencie pojawia się 46 gmin żydowskich wymienionych z nazwy oraz pewna nieokreślona liczba osad na ziemiach białoruskich oraz kilka skupisk położonych na lewym brzegu Dniepru ${ }^{15}$. Chodziło tu zapewne o niewielkie, dopiero kształtujące się gminy w powiecie orszańskim oraz województwie mścisławskim, a także zapewne osiedla na Wołyniu, które nadal uznawały zwierzchność Waadu litewskiego.

Skalę wielkości gmin w pierwszej połowie XVII w. pokazują przykładowe dane zaczerpnięte przede wszystkim z inwentarzy dóbr radziwiłłowskich. W grupie tej największą gminą był Nieśwież. W 1629 r. w mieście było trzydziestu dwóch gospodarzy żydowskich, doliczając do liczby tej nie odnotowanych członków rodzin, możemy założyć, że gmina miała około 190 członków ${ }^{16}$. Drugą większą gminą była Bielica, gdzie w 1635 r.

${ }^{11}$ И. Шиппер, Расселение евреев в Польше и Литве, w: История еврейского народа, red. А.И. Браудо i in., t. 11, Москва 1914, s. 112. Opis metody Schipera patrz powyżej.

${ }^{12}$ S. W. Baron, A Social and Religious History of the Jews, New York-London 1976, s. 16.

${ }^{13}$ С.А. Бершадский, Литовские евреи. История их юридического и общественного положения в Литве от Витовта до Люблинской унии, С.-Петербург 1883, s. 335-336.

${ }_{14} \mathrm{~J}$. Šiaučiūnaitè-Verbickienè, Žydai Lietuvos Didžiosios Kunigaikštystès, Aneks nr 2, s. 341 .

15 S. Dubnov, פנקס המדינא או פינקס ועד הקחלות הרשינות במדינת ליתא [Pinkas państwa albo pinkas rady gmin głównych w państwie litewskim], Berlin 1925 (dalej PML), nr פטת פט W uchwale zostały wymienione następujące gminy: a) pod jurysdykcją Brześcia: Międzyrzecz, Wojń, Janów, Roś, Łomazy, Biała, Pieszczatka, Włodawa, Sławatycze, Kodeń, Wysokie, Mścibów, Kobryń, Horodec, Prużana, Malcz, Sielec, Czarnawczyce, Kamieniec, Szereszowo, Różana, Słonim, Dworzec, Nowogródek, Nieśwież, Słuck, Mińsk, Mohylew, Orsza oraz nie określone gminy na Białorusi; b) pod jurysdykcją Grodna: Indura, Miasteczko, Kuźnica, Nowy Dwór, Osryna, Raduń, Lida; c) pod jurysdykcją Pińska: Kleck, Lachowicze, Chomsk, Brahin, Dubrowica, Wysock, Turów oraz gminy położone na lewym brzegu Dniepru. A. Michałowska-Mycielska, Sejm Żydów litewskich (1623-1764), Warszawa 2014, s. 42.

${ }^{16}$ AGAD, Archiwum Radziwiłłów (dalej: AR), XXV, sygn. 2666, „Inwentarz zamku 
odnotowano 23 gospodarzy - Żydów - czyli gmina mogła liczyć około 140 osób ${ }^{17}$. Także w pierwszej połowie XVII w. funkcjonowała już gmina żydowska w należącym do Sieniawskich Szkłowie, w 1643 r. odnotowano w mieście 11 gospodarzy żydowskich - czyli gmina mogła w tym okresie liczyć około 70 osób ${ }^{18}$. Wydaje się, że w większości miast prywatnych w pierwszej połowie XVII w. gminy żydowskie zaczynały się dopiero kształtować, ich liczebność ograniczała się do kilku rodzin. Stopnie rozwoju gmin w pierwszej połowie XVII w. ilustruje doskonale przykład radziwiłłowskiego Kojdanowa. W 1621 r.w mieście mieszkała jedna rodzina żydowskiego arendarza, 26 lat później odnotowano już 6 żydowskich gospodarstw domowych.Obok starego arendarza osiedlili się tam także jego synowie i zięciowie, funkcjonował również cmentarz ${ }^{19}$.

Inaczej sytuacja wyglądała w miastach królewskich, gdzie funkcjonowały największe gminy. Zachowały się dane jedynie o kilku ośrodkach. Tak oto w 1635 r. na terenie wileńskiej dzielnicy żydowskiej mieszkało około 1310 osób. Wiadomo jednak, że wielu Żydów osiedlało się w innych częściach miasta, dlatego też Izrael Klauzner podniósł liczbę Żydów mieszkających w mieście do 2600 , co wydaje się nieco zawyżonym szacunkiem ${ }^{20}$. W 1639 r. w Nowogródku odnotowano 45 żydowskich gospodarzy, w Mińsku 49, natomiast w Słonimiu 73. Możemy więc przyjąć,

miasta, dworu, folwarku, ziemian i wszystkiej włości nieświeskiej” 1628, 1629. W opracowaniu inwentarzy przyjęłam, że odnotowani w nich zostali jedynie gospodarze głowy rodziny. Do analizy oszacowane zostały pozostałe osoby. Zakładam, że przeciętna rodzina żydowska liczyła 6 osób. Szczegółowa analiza liczebności rodzin żydowskich patrz poniżej, tam także dane bibliograficzne.

${ }^{17}$ AGAD, AR, XXV, sygn. 117, „Inwentarz majętności Bielickiej sprawiony w 2 VI 1635". Gmina żydowska w Bielicy została osadzona w 1626 r., por. AR XXIII, teka 40, plik 4, s. 8, „Nadanie na place dla Żydów w Bielicy”, 22 III 1626.

${ }^{18}$ BC, dział rękopisów 9233, „Inwentarz majętności miasta Szkłowa ze wszystkimi włościami i pożytkami”, 29 I 1643.

${ }^{19}$ AGAD, AR, XXV, sygn. 1697, Inwentarz Kojdanowa, 1621; sygn. 1698, Inwentarz Kojdanowa, 1647. Por. także, M. Nadav, op. cit., s. 138. Arendarze żydowscy w Kojdanowie odnotowani w źródłach są po raz pierwszy w 1588 r.; co charakterystyczne, arenda była do połowy XVII w. trzymana przez jedną rodzinę. S. Alexandrowicz, Osadnictwo żydowskie na ziemiach litewsko-białoruskich od XV-XIX w. (Cechy szczególne), w: Świat NIEpożegany. Żydzi na dawnych ziemiach wschodnich Rzeczypospolitej w XVIII-XX w., red. K. Jasiewicz, Warszawa 2004, s. 57-58. Sposób tworzenia nowych gmin można tłumaczyć nakazami religijnymi, to znaczy starano się przestrzegać zasady, aby w danym mieście osiedlały się od początku przynajmniej dwie rodziny, tak aby zapobiec ewentualnym

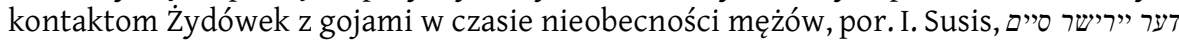
[Żydowski sejm na Litwie i Białorusi w swojej działalności ustawodawczej (1623-1761) według protokołów], „Cajtszrift” 2/3, 1928, s. 53.

${ }^{20}$ I. Klausner, op. cit., s. 47. 
że gmina nowogródzka liczyła około 270 osób, mińska - 294 osoby, słonimska zaś - $438^{21}$.

Dla omawianego okresu nie zachowały się żadne dane liczbowe dotyczące najważniejszych gmin litewskich współtworzących najwyższy organ autonomii żydowskiej - Waad Medinat Lite - czyli Brześcia, Grodna i Pińska. Można jednak założyć, że największą gminą był Brześć, w mieście tym już pod koniec XVI w. odnotowano 90 domów żydowskich ${ }^{22}$. Duża gmina funkcjonowała również w Grodnie, w którym już pod koniec wieku XVI 65 placów w mieście należało do Żydów ${ }^{23}$. Trzecia najważniejsza gmina Pińsk liczyła w 1560 r. 250 osób ${ }^{24}$.

Pierwsze dostępne bardziej szczegółowe dane dotyczą połowy XVII w. Dysponujemy bowiem taryfą dymów WKsL z $1650 \mathrm{r} .{ }^{25}$ Jest to rejestr percepty podymnego, który zawiera tabelaryczne zestawienie sum, jakie wpłacano do skarbu w związku z uchwaleniem w roku 1649 podatku podymnego.

Źródło to było już wykorzystywane do badań demograficznych WKsL, dlatego też nie będę w tym miejscu szczegółowo opisywać sposobu powstania taryfy ${ }^{26}$. Należy jednak zastanowić się nad jej przydatnością do badań nad demografią żydowską. Dotychczas do ustalenia liczebności Żydów na Żmudzi wykorzystał ją Grzegorz Błaszczyk ${ }^{27}$. Taryfa podymnego z $1650 \mathrm{r}$. zawiera informacje o kwocie podatku podymnego wpłaconego przez przedstawicieli poszczególnych kahałów do skarbu państwowego. Uchwała sejmowa nakładała na Żydów, na równi z innymi obywatelami państwa, obowiązek wpłacenia podatku. Podymne było zbierane w kahałach, najpierw ich przedstawiciele samodzielnie dokonywali oszacowania liczby dymów, następnie, kierując się zasadami sformułowanymi w konstytucji sejmowej, dokonywali obliczenia sumy, którą należało wpłacić do skarbu ${ }^{28}$. Nie do końca jasne są zasady wpła-

${ }^{21}$ AGAD, AR, XI, sygn. 96, „Rewizja skazania Żydów nowogrodzkich i czeladzi ich”, 10 VIII 1639; „Aktykacja rewizji u Żydów mińskich”, 10 VIII 1639; „Akt rewizji Żydów słonimskich", 5 X 1639.

${ }^{22}$ И. Шиппер, Расселение евреев в Польше и Литве, s. 111.

${ }^{23}$ P. Borowik, Jurydyki miasta Grodna w XV-XVIII wieku. Stanowy podział nieruchomości, Supraśl 2005, s. 248.

${ }^{24}$ M. Nadav, op. cit., s. 24.

${ }^{25}$ AGAD, AR, VI, II-50, „Regestr percepty podymnego WKsL”, 1650.

${ }^{26}$ J. Morzy, Kryzys demograficzny na Litwie i Białorusi w II połowie XVII wieku, Poznań 1956, s. 87-132; G. Błaszczyk, Żmudź w XVII i XVIII wieku. Zaludnienie i struktura społeczna, Poznań 1985, s. 31-33.

${ }^{27}$ G. Błaszczyk, Liczebność Żydów na Żmudzi,cz. 1, s. 29.

${ }^{28}$ Uchwała sejmowa VL (t. 4, s. 321-322), została powtórzona dosłownie w protokołach posiedzeń Waadu litewskiego; PML, nr תפr. Nie zachowały się żadne materiały źródłowe, które pokazywałyby, w jaki sposób spis był faktycznie przeprowadzany. 
cania, gdyż rejestr odnotowuje wpłaty od Żydów oddzielnie w każdym powiecie oraz kwotę wpłaconą bezpośrednio do skarbu, która jest sumą poszczególnych wpłat dokonanych w powiatach ${ }^{29}$. W taryfie brakuje informacji z kilku powiatów. W części z nich zaludnienie żydowskie było zupełnie znikome, z terenów ważniejszych w całościowym zestawieniu brakuje adnotacji dotyczącej powiatu orszańskiego oraz trzech powiatów województwa mińskiego, czyli powiatu rzeczyckiego, mińskiego oraz mozyrskiego. Jednak założenie, że cała suma wpłacana bezpośrednio dotyczy właśnie tych obszarów, byłoby błędne, gdyż informacje z innego rodzaju źródeł przekonują, iż gminy na tym obszarze nie były w pierwszej połowie XVII w. aż tak liczne. Dlatego też dla dalszych obliczeń zakładam, że kwota wymieniona na końcu zestawienia jest sumą wszystkich pozycji wzmiankowanych wcześniej i nie biorę jej pod uwagę. Dodatkowo należy pamiętać o zatajeniach, budynkach nie objętych spisem (własność gmin) oraz niedokładnościach oraz zniszczeniach wojennych, gdyż w 1650 r. już część WKsL było ogarnięta działaniami wojennymi.

Poważną trudność stanowi ustalenie liczby domów na podstawie sumy wpłacanej do skarbu; będzie ono miało bezpośredni wpływ na końcowy wynik. Konstytucja sejmowa różnicowała wysokość opłaty zależnie od wielkości domu, wprowadzając inną opłatę za większe, mniejsze kamienice, oddzielnie płacono za karczmy ${ }^{30}$. Na podstawie zachowanego materiału nie ma żadnej możliwości wykazania, jaki procent stanowiły budynki duże, jaki zaś małe. Dlatego też należy przyjąć wielkości średnie. W dotychczasowych badaniach, opartych na tej samej podstawie źródłowej, nie różnicowano tego, przyjmując, że z każdego domu wpłacano jedno podymne - to znaczy $0,5 \mathrm{zf}^{31}$. Wydaje się jednak, że wyznaczenie wielkości średniej jest niezbędne. Żydzi osiedlali się głównie w miastach, zapewne jakiś procent ludności mieszkał w dużych kamienicach, wyższy podatek wpłacano również z karczm, które bardzo często były prowadzone przez

${ }^{29}$ W adnotacji w źródle czytamy: „od Żydów, którzy sami do skarbu wnosili oprócz tych, co w powiatach do poborców oddawali”, AGAD, AR, VI, II-50, „Regestr percepty podymnego WKsL", 1650.

30 „w miastach główniejszych mieszczanie od kamienic większych od każdej mają dawać po złotych trzy a z osobna sąsiedzi w tych kamienicach najmujący jednego podymnego po pół złotego [--]. Od mniejszych zaś kamienic po złotych dwa a od sąsiadów w tych kamienicach mieszkających jako wyżej [--]. A od domków, które przy mieście bywają po pół złotego. Na przedmieściach także od większych domów szynkownych po złotych dwa, a od złotych mniejszych po pół złotego [--]. W miasteczkach zaś mniejszych od kamienic większych i domów szynkownych po złotych dwa, od mniejszych domków po pół złotego”, VL 4, s. 321-322, „Podymne w Wielkim Księstwie Lit.". Uchwała ta została dosłownie powtórzona również w protokołach Waadu litewskiego, również zwrócono uwagę na zróżnicowanie budynków.

${ }^{31}$ G. Błaszczyk, Żmudź w XVII i XVIII wieku, s. 31. 
Żydów. Dlatego też dla dalszych obliczeń przyjęłam współczynnik 1,5 zł od budynku. Średnia ta zostanie zastosowana dla całego kraju. Żydzi wpłacili do skarbu państwowego w sumie 6771 zł, będących równowartością pięciu podymnych, pojedyncze podymne od Żydów wynosiło 1354,3 zł. Czyli w 1650 r. w WksL było około 900 (dokładnie 903) dymów żydowskich.

Średnia liczba dymów żydowskich w WKsL w połowie XVII w. jest jedynie podstawą do wyliczenia liczby ludności. Dla dalszych obliczeń kluczowa jest liczebność dymu żydowskiego ${ }^{32}$. W dotychczasowych badaniach uwzględniających to źródło obliczano liczebność dymu chrześcijańskiego na 8 osób. W badaniach demograficznych nad XVII w., opartych na innych źródłach, proponowano jednak także niższe współczynniki - od 6,5 (Henryk Łowmiański) do 7 osób (Stanisław Alexandrowicz, Maria Topolska) ${ }^{33}$. Inny wskaźnik stosowano w stosunku do dymów żydowskich, zakładając, że te były bardziej liczne ${ }^{34}$. I. Schiper przyjmował 28 osób na dym ${ }^{35}$, natomiast Maria Łowmiańska 27,7, a I. Klauzner 26,7 osoby na dym ${ }^{36}$. G. Błaszczyk przyjął dla miasteczek żmudzkich współczynnik 14 osób ${ }^{37}$. Przy określaniu liczebności domu żydowskiego pomocne są, mimo oczywistych różnic, badania prowadzone dla Korony. Ze względu na doskonałą podstawę źródłową oraz podobny okres współczynnik wyliczony przez Adama Tellera dla Poznania wydaje się dość wiarygodny. Autor ten podaje, że w domu żydowskim mieszkało przeciętnie 21,9 osoby ${ }^{38}$.

Zachowane litewskie dokumenty pozwalają także na próbę szacunku zaludnienia dymu żydowskiego. Większość pochodzi jednak z drugiej połowy XVII lub z XVIII w.Jak wiadomo, liczebność dymu nie jest wartością stałą, jej wysokość zmienia się zależnie od badanego okresu historycznego

${ }^{32} \mathrm{Na}$ temat obliczania wielkości dymów w WKsL por. H. Łowmiański, Zaludnienie państwa litewskiego w wieku XVI, Poznań 1998, s. 129-157.

${ }^{33}$ S. Alexandrowicz, Zaludnienie miasteczek Litwy i Białorusi $w$ XVI $i$ w pierwszej połowie XVII w., w: idem, Studia z dziejów miasteczek Wielkiego Księstwa Litewskiego, Toruń 2011, s. 139; M. B. Topolska, Dobra szkłowskie na Białorusi Wschodniej w XVII i XVIII w., Warszawa 1969, s. 22. Ten sam przelicznik stosuje również Otton Hedemann, Dzisna i Druja, magdeburskie miasta, Wilno 1934, s. 46.

${ }^{34}$ G. Błaszczyk, Liczebność Żydów na Żmudzi,cz. 1, s. 23-24.

${ }^{35}$ И. Шиппер, Расселение евреев в Польше и Литве, s. 106-111.

${ }^{36}$ M.Łowmiańska, op. cit., s. 222; I. Klausner, op. cit., s. 47.

${ }^{37}$ G. Błaszczyk, Liczebność Żydów na Żmudzi, cz. 1, s. 30.

${ }^{38}$ A. Teller, חיים בצוותא הרחוב היהודי של פוזנן במחצית הרישונה של המאה השבע עשרה [Dzielnica żydowska w Poznaniu w pierwszej połowie XVII w.], Jerusalem 2003, s. 65. Por także Z. Guldon, W. Kowalski, The Jewish Population and Family in the Polish-Lithuanian Commonwealth in the second half of the $18^{\text {th }}$ Century, "The History of the Family" 8, 2003, 4, s. 517-530 - przy czym analiza dotyczy wieku XVIII oraz terenów Korony, dlatego też wydaje się w mniejszym stopniu przydatna do moich rozważań. 
oraz położenia geograficznego. Niejednokrotnie obserwujemy wyraźne różnice w ramach tego samego okresu oraz rejonu geograficznego. Na podstawie porównania danych zaczerpniętych z taryf podymnego z $1690 \mathrm{r}$., taryf pogłównego żydowskiego z 1765 r., rachunków podymnego z 1711 r. oraz inwentarza dóbr prywatnych z 1750 r. ustaliłam, że wielkość dymu żydowskiego waha się między 9,4 a 26,7 osoby ${ }^{39}$, czyli średnio 18,05 osoby na dym. Biorąc pod uwagę wcześniejsze badania, w których wykorzystywano wyższe współczynniki, oraz fakt, że obliczenia oparłam na materiale osiemnastowiecznym, przyjmuję jako średnią wartość zaludnienia domu żydowskiego 20 osób. Wykorzystywane tutaj źródło nie pozwala niestety na zróżnicowanie między miastami mniejszymi i większymi ani między gminami położonymi w zachodnich i wschodnich powiatach WKsL. Zdaję sobie sprawę z oczywistych różnic, przedstawiony tutaj współczynnik traktując jako średnią. Dodatkowo należy pamiętać, że na tak dużym obszarze geograficznym występowały na pewno różnice między poszczególnymi powiatami. Stosując taki przelicznik, wyliczam, że w WKsL mieszało w 1650 r. około 18 tys. (dokładnie 18 060) Żydów.

W taryfie nie uwzględniono jednak wpłat z następujących powiatów: wiłkomierskiego, brasławskiego, starodubowskiego, orszańskiego, mińskiego, mozyrskiego, rzeczyckiego oraz województwa inflanckiego. Trudno jednoznacznie rozstrzygnać, dlaczego nie wymieniono Żydów w tych powiatach. Można założyć, że w województwie inflanckim oraz powiatach brasławskim i rzeczyckim liczba ludności żydowskiej była znikoma. Hipotezę tę wydają się potwierdzać dane z połowy XVIII w., z których wynika, iż nawet wtedy był to obszar prawie nie zamieszkany przez Żydów ${ }^{40}$. Gminy powiatu mozyrskiego mogły być już zniszczone po przejściu oddziałów Bohdana Chmielnickiego. Również powiat wiłkomierski nie należał do najważniejszych obszarów zasiedlenia żydowskiego. Prawdopodobne jest, że Żydzi mieszkający tam wpłacili podatek razem z gminą wileńską. Zapewne podatek z powiatu starodubowskiego, w którym zaludnienie żydowskie

${ }^{39}$ Pierwsza wartość została wyliczona na podstawie rejestrów podymnego województwa wileńskiego (Metryka Litewska. Rejestry podymnego Wielkiego Księstwa Litewskiego. Województwo wileńskie, s. 60-62), z oświadczenia lustratorów podymnego województwa nowogródzkiego z 1711 r. wynika 24,7 osoby (AGAD, AR, XV, t. 7, p. 4, s. 1886-1888, „Oświadczenie lustratorów województwa nowogródzkiego w sprawie poborów po morowym powietrzu", 13 III 1711), z rewizji miasta Słucka z 1750 r. 10,66 osoby (AGAD, AR, XXV, sygn. 3837, Rewizja miasta Słucka, 1750), a z rewizji pogłównego żydowskiego województwa wileńskiego 26,7 osoby (LVIA, Senieji Aktai [dalej: SA] 3728, Rewizja pogłównego żydowskiego województwa wileńskiego).

${ }^{40}$ W 1765 r. w województwie inflandzkim odnotowano 2996 Żydów; w powiecie rzeczyckim 4125 Żydów; w brasławskim 2756 Żydów; por J. Šiaučiūnaitė-Verbickienè, Žydai Lietuvos Didžiosios Kunigaikštystès, s. 345-364. 
było także raczej niewielkie, został wpłacony za pośrednictwem gminy z Zawierowicz, drugiej większej gminy w województwie smoleńskim. Dla rachunku znaczące mogą być natomiast gminy położone na wschodzie, to znaczy w powiecie orszańskim oraz województwie mińskim. Nie wiadomo, dlaczego nie zostały uwzględnione w taryfie. Prawdopodobnie wpłaciły podatek za pośrednictwem gminy brzeskiej, ponieważ w strukturze autonomii żydowskiej tereny te podlegały Brześciowi. Możliwe jest jednak również, że podatek $z$ tych kahałów wpłynął do skarbu bezpośrednio lub tė̇ został przekazany razem z opłatą pobraną od mieszczan. Dlatego też należy uzyskaną tutaj wartość powiększyć o dymy znajdujące się poza wymienionymi gminami. Jak wynika z badań Pinkasa Marka, w województwie mińskim gminy żydowskie znajdowały się w Mińsku, Rakowie, Radoszkowicach i Kojdanowie ${ }^{41}$. Dokładniejsze dane z pierwszej połowy XVII w. zachowały się jedynie dla gminy mińskiej oraz kojdanowskiej. W pierwszej mieszkało około 240 osób, druga była zdecydowanie mniej liczna - w 1647 r.mieszkało tam około 30 osób $^{42}$. Dla dwóch pozostałych gmin dostępne są tylko dane z drugiej połowy XVII w., z których wynika, że gmina rakowska była nieznacznie większa od gminy kojdanowskiej. W 1677 r. zamieszkiwało ją około 90 osób. A w tym samym roku w Radoszkowicach odnotowano około 55 osób $^{43}$.Zważywszy na zniszczenia wojenne połowy XVII w., można założyć, iż w pierwszej jego połowie gminy te były podobnej wielkości. Przyjmuję więc, że w województwie mińskim mieszkało około 400 Żydów.

Trudniej ustalić liczbę ludności żydowskiej powiatu orszańskiego. Jak wynika z badań P. Marka, gminy żydowskie znajdowały się w Orszy, Szkłowie, Mohylewie, Czausach, Czerechowie, Starym Bychowie, Smolanach i Kopysi ${ }^{44}$. Szczegółowe dane z pierwszej połowy XVII w. mamy tylko dla Szkłowa - w 1643 r. mieszkało tam około 50 Żydów - oraz Kopysi, gdzie mieszkało około 40 osób $^{45}$. Z powodu braku informacji dotyczących pozostałych ośrodków w pierwszej połowie XVII w., musimy

${ }^{41}$ И. Шиппер, Расселение евреев в Польше и Литве, patrz mapa autorstwa P. Marka dołączona do artykułu.

${ }^{42}$ AGAD, AR, XI, sygn. 96, „Aktykacja rewizji u Żydów mińskich”, 10 VIII 1639; AGAD, AR, XXV, sygn. 1698, Inwentarz Kojadnowa, 1647.

${ }^{43}$ LVIA, SA, 3417, „Księga rejestrów delatowych i perceptowych”, 1677, k. 1831.

${ }^{44}$ Ibidem.

${ }^{45}$ BC, 9233, „Inwentarz majętności miasta Szkłowa ze wszystkimi włościami i pożytkami, do niego należącymi spisany przeze mnie Stanisława Bohusza na Rewizję od jaśnie wielmożnego Pana Adama Hieronima z Gronowa Sieniawskiego hrabi na Szkłowie i Myszy do Szkłowa zesłany”, 29 I 1643; AGAD, AR, XXV, sygn. 1766, „Inwentarz majętności oświeconego Księcia Jw. Ksci Pana Bogusława Radziwiłła Księcia na Birżach Dubinakach Słucku koniuszego WXL [--] sporządzony przez nas Samuela Goliwskiego Janusza Totkowicza roku 1650 informo pożytków zamkowych i folwarcznych i miejskich miasta Kopysi i Brani włości poddanych i ziemiany bojarów czynszów po- 
sięgnąć do późniejszych danych. Dane z drugiej połowy XVII w. pokazują hierarchię wielkości gmin. Największa była gmina w Mohylewie (w $1676 \mathrm{r}$. około 300 osób). Do mniejszych należały kahały w Orszy (w 1676 r. około 70 osób), w Czausach (w 1676 r. około 50 osób), w Smolanach (w 1676 r. około 40 osób). Nie mam żadnych danych dotyczących Starego Bychowa, Czerechowa. Wydaje się jednak, że gminy te nie były zbyt liczne. Można założyć, że w gminach powiatu orszańskiego mieszkało około 550 osób, czyli do wartości podanej powyżej należy doliczyć około 900 osób. Podsumowując, można stwierdzić, iż w roku 1650 w WKsL mieszkało około 18900 (dokładnie 18 960) Żydów. Porównując otrzymany wynik z danymi z połowy XVI w., widzimy, iż w ciągu prawie 100 lat liczba ludności wzrosła o niecałe 10000 osób. Zaważywszy na fakt, iż był to okres rozwoju ekonomicznego tych ziem, a dzięki zacieśnieniu związków między WKsL a Koroną otworzyły się większe możliwości dla migracji żydowskiej, otrzymane powyżej dane wydają się bliskie rzeczywistości.

Przyjmując ogólną liczbę ludności WKsL w tym okresie na 3864 416, Żydzi stanowiliby około $0,51 \%$ populacji. W skali całego kraju jest to procent znikomy ${ }^{46}$. Wiadomo jednak, że ludność żydowska osiedlała się przede wszystkim w miastach, dlatego też ważny jest jej odsetek wśród ludności miejskiej. Przyjmując za Józefem Morzym, że w WKsL w pierwszej połowie XVII w. było 560 tys. ludności miejskiej, Żydzi stanowili około 3,5\% jej ogó$\nmid u^{47}$. Należy jednak podkreślić, że w niektórych ośrodkach odsetek ludności żydowskiej był dużo większy, np. w Pińsku w 1648 r. Żydzi stanowili około $20 \%$ mieszkańców miasta ${ }^{48}$.

\section{Sytuacja demograficzna w drugiej połowie XVII w.}

Pierwszym podstawowym problemem stojącym przed badaczem opisującym sytuację demograficzną WKsL w drugiej połowie XVII w.jest określenie skali zniszczeń spowodowanych powstaniem Chmielnickiego, potopem

\footnotetext{
datków od bojarów przychodzących podany Je Msci Panu [--] Kaszeli przy liście zapisie arendowanym do roku 1651 podanym".

${ }^{46}$ Szacunki S. W. Barona, iż Żydzi stanowili około 4-5\% ludności kraju, są dla WKsL zdecydowanie za wysokie, S.W. Baron, op. cit., s. 207.

${ }^{47}$ J. Morzy, op. cit., s. 199. W wcześniejszych badaniach Zinowij Kopyski podawał, że Żydzi stanowili około 1,5\% ludności miejskiej w miastach białoruskich, wydaje się jednak, iż wartość wyliczona na podstawie szacunków pogłównego jest nieco za niska, 3. Ю. Копысский, Экономическое развитие городов Белоруссии в XVI - первой половине XVII в., Минск 1966, s. 50.

${ }^{48}$ M.Nadav, יהודים וערונים בפינסק במאות ה 16 וה 17 (עד 1648) [Żydzi i mieszczanie w Piń-

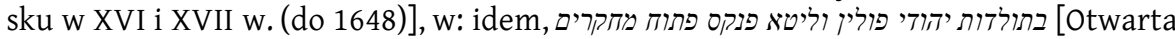
księga. Prace z historii Żydów polskich i litewskich], Tel Aviv 2003, s.11.
} 
szwedzkim oraz najważniejszą dla WKsL wojną polsko-rosyjską. Najnowsze badania dotyczące Korony wykazały, że bilans strat żydowskich nie był tak wielki, jak przyjmowała tradycyjna historiografia żydowska ${ }^{49}$. Teza ta jest także trafna dla WKsL. Dodatkowo należy pamiętać, że obszar ten w niewielkim stopniu ucierpiał w czasie powstania Chmielnickiego, mniej znacząca w skutkach była również wojna ze Szwecją ${ }^{50}$.

Do depopulacji WKsL w przyczyniła się przede wszystkim późniejsza okupacja moskiewska. Analizując skalę zniszczeń oraz strat demograficznych, nie wolno jednak traktować całego obszaru państwa w ten sam sposób. Nie wszystkie bowiem tereny były bezpośrednio dotknięte działaniami wojennymi, nie wszędzie stacjonowały obce wojska ${ }^{51}$. Na terenach okupowanych przez wojska Aleksego Michałowicza większość gmin przestała istnieć. Część ludności żydowskiej zginęła w czasie działań wojennych, w pogromach organizowanych przez wojska rosyjskie i kozackie lub też została uprowadzona na tereny państwa moskiewskiego - losy gminy w Mohylewie są tego dobrą egzemplifikacją ${ }^{52}$.

Skalę zniszczeń można zilustrować przykładami kilku ośrodków. Pierwszy z nich to należąca do Radziwiłłów birżańskich Kopyś. Przed połową XVII w. w mieście funkcjonowała niewielka gmina żydowska, w 1650 r. odnotowano 13 żydowskich gospodarzy. Natomiast w $1661 \mathrm{r}$. mieszkał tam tylko żydowski arendarz z rodziną. Pozostałe nieruchomości należące wcześniej do Żydów zostały zajęte przez chrześcijan ${ }^{53}$. Pewną część ludności żydowskiej przesiedlono na tereny moskiewskie zjawisko to dobrze ilustruje przykład Szkłowa. W 1661 r. w mieście odnotowano jedynie dwóch Żydów, przy ich nazwiskach znajdujemy ad-

${ }^{49}$ S. Stampfer, What actually happened to the Jews of Ukraine in 1648?, „Jewish History" 17, 2003, s. 207-227; por także A. Teller, Jewish Literary Response to the Events of 1648/1649 and a Polish-Jewish Consciousness, w: Culture Front. Representing Jews in Eastern Europe, red. B. Nathans, G. Safran, Philadelphia, Pa. 2007, s. 17-45.

${ }^{50} \mathrm{H}$. Wisner, Wielkie Księstwo Litewskie w przededniu potopu, w: Rzeczpospolita w latach potopu, red.J. Wijaczka, J. Muszyńska, Kielce 1996, s. 17.

${ }^{51}$ Por. B. Pendzich, Los Żydów na Białej i Czarnej Rusi w czasie „nieznanej wojny” 16541667, w: Żydzi i judaizm we współczesnych badaniach polskich, red. K. Pilarczyk, Kraków 1997, s. 155-161.

${ }^{52}$ K. Bobiatyński, Kampania zimowo-wiosenna wojsk Janusza Radziwiłła 1654-1655, w: Staropolska sztuka wojenna XVI-XVII wieku. Prace ofiarowane profesorowi Jaremie Maciszewskiemu, red. M. Nagielski, Warszawa 2002, s. 190.

${ }^{53}$ AGAD, AR, XXV, sygn. 1768, „Inwentarz majętności kopyskiej po odebraniu z rąk moskiewskich”, 10 I 1661. Analizując sytuację w Kopysi, należy pamiętać, że dobra Radziwiłłów birżańskich ze względu na oskarżenia o zdradę wyjątkowo ucierpiały w tym okresie, por. A. Rachuba, Sprawa dóbr Radziwiłłów birżańskich w latach 1655-1662, „,Miscellanea Historico-Archivistica" 1997, t. 7, s. 50-70. 
notacje, że wrócili z Moskwy. Pozostali właściciele żydowscy nie zdążyli jeszcze wrócićn ${ }^{54}$.

Nie wszystkie gminy zostały zniszczone. Przykładem kahału, w którym, jak się wydaje, stan demograficzny z okresu przed wojnami połowy XVII w. nie uległ znacznej zmianie, jest także radziwiłłowski Kojdanów. W mieście tym w 1647 r. odnotowano 6 rodzin żydowskich. W 1669 r. zapisano w inwentarzu 5 gospodarzy posiadających place i domy ${ }^{55}$. Jak wynika z badań Mordechaja Nadava, gmina w Pińsku po zakończeniu działań wojennych wręcz wzmocniła się demograficznie ${ }^{56}$.

Analizując skalę zniszczenia gmin żydowskich w połowie XVII w., należy oddzielnie traktować miasta królewskie i prywatne. Wiadomo bowiem, że w większości wypadków dobra prywatne ucierpiały mniej. W trakcie działań wojennych najbardziej zniszczone zostały miasta królewskie, a zatem największe oraz najważniejsze gminy żydowskie. 0 zniszczeniu gminy brzeskiej i grodzieńskiej informują pośrednio zwolnienia podatkowe, jakie zostały wydane dla obydwu gmin bezpośrednio po zakończeniu działań wojennych ${ }^{57}$.

Analizując znaczenie kryzysu połowy XVII w., należy pamiętać jeszcze o kilku czynnikach, widocznych dopiero wtedy, gdy uwzględnimy źródła inne niż inwentarze. W okresie tym WKsL było obszarem wzmożonej emigracji żydowskiej. Duże grupy uciekinierów z zajętej powstaniem Chmielnickiego Ukrainy znalazły tutaj schronienie. Szczegółowa analiza danych z inwentarzy wydaje się potwierdzać hipotezę o dużym znaczeniu uchodźców dla niektórych terenów WKsL. W tym kontekście można przywołać przykład radziwiłłowskiej (birżańskiej) Bielicy, gdzie w okresie między 1635 a 1652 r. zanotowano dwukrotny wzrost populacji żydowskiej. W 1635 r. mieszkało tam 23 gospodarzy Żydów, 17 lat później liczba ta urosła do 45. Natomiast w 1669 r. ponownie odnotowano 23 dymów żydowskich, 50\% wzrostu odnotowanego w ciągu 17 lat musiało zostać wywołane czynnikiem zewnętrznym. Bielica leżała nieco na uboczu działań wojennych, wiele osób mogło się tam schronić po uspokojeniu sytuacji wrócić jednak do swoich gmin macierzystych ${ }^{58}$.

${ }^{54}$ BC, 9241, „Inwentarz miasta Szkłowa miasteczek i wszystkiej włości do niego należącej. Inwentowany po ustąpieniu moskiewskim w roku 1661".

${ }^{55}$ AGAD, AR, XXV, sygn. 1700, Inwentarz Kojdanowa, 1669.

${ }^{56}$ M. Nadav, The Jews of Pinsk, s. 183. Tezę tę powtarza również A. Teller, The Shtetl as an Arena for Polish-Jewish Integration in the Eighteenth Century, „Polin” 17, 2004, s. 31.

${ }^{57}$ J. Morzy, op. cit., s. 173. VL 4, s. 821-822, „Miasto Brześć, Szereszów i Kamienic Litewski”; „Miasto Grodno, Nowogródek i Merecz”.

${ }^{58}$ AGAD, AR, XXV, sygn. 77, „Inwentarz majętności Bielickiej”, 20 VI 1635; sygn. 179, „Inwentarz majętności bielickiej”, 1652; sygn. 82, „Inwentarz majętności bielickiej z folwarkami do niej należącymi 1669". 
Potwierdzenie hipotezy o dużym znaczeniu wewnętrznych migracji dla stosunków demograficznych w społeczności żydowskiej tego okresu odnajdujemy także w innego rodzaju zarówno polskich, jak i żydowskich źródłach. W połowie XVII w. w kilku miastach prywatnych zostały wydane przywileje ograniczające prawa Żydów do mieszkania, dotyczące przede wszystkim obcych napływających do miasta. Przykładem mogą być w tym miejscu Słuck oraz Kiejdany ${ }^{59}$. Problem uchodźców był omawiany także na forum Waadu litewskiego - po raz pierwszy na posiedzeniu w 1650 r. Fakt, że zwierzchnie władze autonomiczne wprowadziły z jednej strony bardzo szczegółowe zasady, w jaki sposób należy przyjmować uciekinierów, z drugiej strony starały się o ułożenie stosunków w gminach ich przyjmujących, świadczy, iż było sporo ludności napływowej, a jej przyjęcie stanowiło pewien problem dla niewielkich gmin litewskich ${ }^{60}$.

Znaczenie wojen połowy XVII w. dla sytuacji demograficznej Żydów w WKsL jest najbardziej widoczne w momencie porównania danych demograficznych z pierwszej i drugiej połowy stulecia. Specyfika zachowanych materiałów źródłowych pozwala jedynie na pokazanie pewnych tendencji w rozwoju demograficznym, nie jest natomiast możliwe przedstawienie szczegółowych danych liczbowych.

Do opisu sytuacji demograficznej ludności żydowskiej w drugiej połowie XVII w. wykorzystane zostaną przede wszystkim dane zaczerpnięte z abjurat pogłównego generalnego uchwalonego dla WKsL po raz pierwszy w $1676 r{ }^{61}$ Podatek ten obowiązywał całą ludność mieszkającą na terenie państwa. Żydom również, niezależnie od stałego pogłównego żydowskiego, nakazano wpłacanie pogłównego ogólnego. Wysokość podatku ustalano na podstawie abjurat, tworzonych bezpośrednio w gminach, które następnie były zaprzysięgane $\mathrm{w}_{\text {grodach }}{ }^{62}$. W abjuratach uwzględniano kobiety i mężczyzn powyżej 10. roku życia. Zwolnienia z podatku obowiązywały jedynie młodsze dzieci oraz osoby ubogie.

${ }^{59} \mathrm{~W}$ obydwu miastach wprowadzono w tym okresie przywileje ograniczające osadnictwo obcych Żydów, jak wynika z akt miejskich słuckich w mieście osiedliła się duża grupa uciekinierów, por. AR, XXIII, t. 18, p. 1 (Przywilej Bogusława Radziwiłła nakazujący wygnanie obcych) oraz AR, XXIII, t. 134, p. 1, s. 229 nn. (protokoły posiedzeń rady miejskiej słuckiej, na których poruszano problem uchodźców żydowskich).

${ }^{60}$ Szczegółowa analiza uchwał Waadu dotyczących uchodźców, A. Gomer, Beiträge zur Kultur- und Sozialgeschichte des Lithauischen Judentums im 17 und 18 Jahrhundert, Bochum 1930, s. 33; М. Вишницерь, Литовский Ваадъ, w: История еврейского народа, t. 11 , s. 195.

${ }^{61}$ R. Rybarski, Skarb i pieniądz za Jana Kazimierza, Michała Korybuta i Jana III, Warszawa 1939, s. 195.

${ }^{62}$ Wilnianie. Żywoty siedemnastowieczne, oprac. D. Frick, Warszawa 2008, nr 100. 
Przed szczegółową analizą źródła należy zastanowić się nad jego wiarygodnością. W dotychczasowych badaniach uważa się, że rejestry pogłównego generalnego są źródłem mało wiarygodnym, ale w wielu wypadkach jedynym pozwalającym na stawianie jakichkolwiek hipotez ${ }^{63}$. Stwierdzenie to wydaje się szczególnie trafne dla badań nad demografią żydowską. Materiały litewskie nie były dotychczas wykorzystywane w badaniach żydowskich. Część analogicznych materiałów koronnych była wykorzystywana w badaniach nad demografią żydowską, jednak w przeciwieństwie do materiałów dotyczących ludności chrześcijańskiej nie zostały poddane krytycznej ocenie źródłowej, nie oceniono ich wiarygodności (np. poprzez porównanie z inwentarzami dóbr) ${ }^{64}$. Krytyka żydowskich taryf pogłównego jest niezbędna. Należy bowiem pamiętać, że taryfy powstawały bezpośrednio w kahałach, dlatego też można przypuszczać, że zatajenia czy opuszczenia były inne niż w przypadku taryf chrześcijańskich ${ }^{65}$.

Na tym etapie badań nie jestem w stanie przeprowadzić szczegółowej analizy źródła. Jednak w celu wstępnego ustalenia wiarygodności danych $\mathrm{z}$ abjurat pogłównego porównałam je $\mathrm{z}$ danymi zaczerpniętymi z inwentarzy dóbr magnackich. Materiał porównawczy jest niestety dosyć ubogi. Porównanie wykazało dużą wiarygodność źródła. We wszystkich wypadkach dane zaczerpnięte z inwentarzy w mniejszym lub większym stopniu pokrywają się z danymi z abjurat. Mimo pewnych nieścisłości we wszystkich wypadkach zachowana jest ta sama skala wielkości ${ }^{66}$.

${ }^{63}$ Szczegółowa krytyka źródła w badaniach na ludnością chrześcijańską Korony por. M. Kopczyński, Studia nad rodzina chłopska w Koronie w XVII-XVIII w., Warszawa 1998, s. 38-42; A. Laszuk, Ludność województwa podlaskiego w drugiej połowie XVII w., Warszawa 1999, s. 17-43.

${ }^{64}$ И. Шиппер, Податное обложение Евреевъ, w: История еврейского народа, t. 11, s. 300-320; Z. Guldon, W. Kowalski, Ludność żydowska w miastach w polskich w II połowie XVII wieku, w: Ojczyzna bliższa i dalsza. Studia historyczne ofiarowane Feliksowi Kirykowi w 60 rocznicę urodzin, red. J. Chrobaczyński, A. Jureczko, M. Śliwa, Kraków 1993, s. 485-496; Z. Guldon, Ludność żydowska w miastach województwa sandomierskiego, BŻIH 1982, nr 123/124, s. 17-29; idem, Ludność żydowska w miastach małopolskich $w$ drugiej połowie XVII wieku, w: Żydzi w Małopolsce. Studia z dziejów osadnictwa i życia społecznego, red. F. Kiryk, Przemyśl 1991, s. 85-97.

${ }^{65}$ Zgodnie z uchwałą sejmu 1676 r. Żydzi zobowiązani byli: „Subsydium zaś generale zaprzysięgać będą w grodzie, przez starszych i szkolników swych i dwiema ratami tak jako plebeij wypłacać, do poborców województw i powiatów powinni będą", VL 5, s. 425, „Pogłówne żydowskie”. Niestety nie zachował się żaden materiał źródłowy opisujący faktyczny sposób przeprowadzania spisu. Wiadomo jedynie, że starsi gmin zgłaszali do komisji poborowych gotowe taryfy.

${ }^{66}$ Porównane zostały dane dotyczące: starostwa krzyczewskiego - w abjuracie podano 27 osób, inwentarz sporządzony pięć lat wcześniej podaje 14 mężczyzn; Dawidgródek - w abjuracie podano 32 osoby, a w rok wcześniejszym inwentarzu 14 mężczyzn. W obydwu wypadkach po doliczeniu kobiet otrzymujemy wartości 
Analiza danych pochodzących z abjurat pogłównego generalnego wymaga ustalenia statystycznej wielkości rodziny żydowskiej. Niestety, brak badań dotyczących struktury rodziny żydowskiej w WKsL w połowie XVII w. ${ }^{67}$ Należy pamiętać, że statystyczna wielkość rodziny nie jest stała, zmienia się wraz z obszarem geograficznym, okresem historycznym $^{68}$. Zasadniczo przyjmuje się, że rodziny żydowskie były bardziej liczne niż chrześcijańskie ${ }^{69}$. W teoretycznych badaniach demograficznych nad żydowską rodziną wschodnioeuropejską zakłada się, że każda kobieta rodziła 5-6 dzieci, z których jedynie część dożywała wieku dorosłego ${ }^{70}$. Dla Korony przyjmuje się wielkości oscylujące między 4,2 a 5 osobami ${ }^{71}$. $\mathrm{Z}$ analizy litewskich, mało wiarygodnych, późno osiemnastowiecznych źródeł fiskalnych wynika, że przeciętna rodzina to 3,3 osoby ${ }^{72}$. Natomiast analiza inwentarza Słucka z 1750 r. pokazuje, iż przeciętna rodzina żydowska składała się z około 8 osób ${ }^{73}$. Ze zgromadzonych danych wynika, że wielkość przeciętnej rodziny żydowskiej w WKsL oscylowała między 3 a 8 osobami. Dla dalszej analizy została wybrana średnia wielkość 6 osób na rodzinę żydowską. Ponieważ abjuraty zawierają informacje dotyczącą dorosłych kobiet i mężczyzn, dla otrzymania przybliżonej liczby całej ludności WKsL dane zaczerpnięte $\mathrm{z}$ abjurat pomnożono przez trzy. Abjuraty nie zachowały się dla wszystkich obszarów WKsL. Brak jakichkolwiek danych dotyczących następujących powiatów: rzeczyckiego, mozyrskiego, witebskiego, brasławskiego, upickiego, grodzieńskiego, wileńskiego, a także Żmudzi. Informacje dotyczące województwa

podobne do tych z abjurat, AGAD, AR, XXV, sygn. 674, Inwentarz starostwa krzyczewskiego, 1669; sygn. 1923, Inwentarz Dawidgródka, 1675.

${ }^{67}$ G.D Hundert, Jewish Children and Childhood in Early Modern East Central Europe, w: The Jewish Family Metaphor and Memory, red. D. Kraemer, New York 1989, s. 85-94; idem, Approaches to the History of Jewish Family in Early Modern Poland-Lithuania, red. S. M. Cohen, P.E. Hyman, New York-London 1986, s. 17-28. Klasyczne analizy funkcjonowania rodziny żydowskiej w świetle regulacji religijnych w środowisku Żydów aszkenazyjskich por. J. Katz, Family Kinship and Marriage Among Ashkenazim in the Sixteenth to Eighteenth Centuries, , Jewish Journal of Sociology”, vol. 1, 1959, s. 4-22.

${ }^{68}$ Z. Guldon, W. Kowalski, op. cit., s. 517-530.

${ }^{69}$ С.А. Бершадский, op. cit., s. 335-336. Nie wiadomo, dlaczego autor wybrał liczbę 16 jako górną granicę.

70 S. Della-Pergola, Some Fundamentals of Jewish Demographic History, ,Papers in Jewish Demography" 1997, s. 23.

${ }^{71}$ Pierwsza wielkość pochodzi z taryf pogłównego żydowskiego z 1764 r., za: R. Mahler, Żydzi w dawnej Polsce, s. 153. Druga - z badań Jakuba Goldberga na temat Wieruszowa J. Goldberg, Społeczność żydowska w dawnym miasteczku. Żydzi w dawnym Wieruszowie, BŻIH 1966, nr 59, s. 6.

${ }^{72}$ A. Michałowska, Rodzina żydowska $w$ Radoszkowicach $w$ końcu XVIII wieku, KH 110, 2003, 1, s. 65.

${ }^{73}$ AGAD, AR, XXV, sygn. 3837, Inwentarz Słucka, 1750. 
nowogródzkiego pochodzą z abjurat przechowywanych w Archiwum Radziwiłłowskim, dlatego też dotyczą tylko miast należących do tej rodziny. Z powiatu wileńskiego zachowały się jedynie dane dotyczące samej stolicy.

W wypadku pozostałych powiatów Żydzi często byli zgłaszani razem z mieszczanami-chrześcijanami. Tego typu informacja jest dla moich badań zupełnie bezużyteczna, gdyż nigdy nie wiadomo, jaki procent stanowili Żydzi. Zdarzają się także adnotacje o niewykonaniu nakazanej Żydom przysięgi. W materiałach litewskiej komisji skarbowej zachowały się także dokumenty dotyczące wpłaty podatku lub zaległości.Jednak w zestawieniu informacje te zostały pominięte, gdyż nie mówią nic o liczebności gminy.

Żydzi w Wielkim Księstwie Litewskim w drugiej połowie XVII w.

Dane z abjurat pogłównego żydowskiego z lat 1676-1677

Miejsce

\section{Powiat brzeski}

Brześć

Biała

Prużana

Włodawa

Kodeń

Szereszów

Sielc

Sławatycze

Kodeń

Wisznice

Janów

Kobryń

Bereza

Wojń

Łomazy

Horodec

Starostwo kamienieckie

Dywin

Opole i Spiecki

Pieszczotka

Hanna

Trościeniec

Milejczyce

Malecz

CAŁOŚć

Powiat wiłkomierski

(zgłoszony centralnie)
Dane $\mathrm{z}$ abjuraty

616

86

65

61

60

59

55

52

48

43

40

40

38

37

35

30

25

16

15

15

14

10
Po doszacowaniu osób nie objętych podatkiem

1848

258

195

183

180

177

165

156

144

129

120

120

114

111

105

90

75

48

45

45

42

30

30

18

4428 
Powiat słonimski

Różana

74

Słonim

Dzięcioł

Kosów

Bistyń

Połonka

Mołczadź

Jelnia

CAŁOŚć

Powiat lidzki

Lida

Raduń

Wasilów

Osryń

Różanka

CAŁOŚć

Powiat orszański

Mohylew

Szkłów

Tołczyn

Białynicze

Orsza

Kopyś

Czausy

Smolany i Obolce

Bóbr

Hołowczyc

Kniazice

Homel

Romanów

CAŁOŚć

Powiat Piński

Pińsk

Janów

Turów

Dawidgródek

Solin

Drohiczyn

CAŁOŚć

Powiat wołkowyski

Mścibów

Wołpiadź

Lubecz

CAŁOŚĆ
60

43

32

18

14

13

6

260

53

105

30

26

25

239

159

315

90

78

75

717

267

177

165

93

72

72

54

45

39

33

24

27

15

1083

359

251

753

46

138

45

32

30

135

96

90

84

1296

432

231

693

66

198

43

129

340

1020 
Województwo połockie

Połock

24

14

38

CAŁOŚć

Województwo mścisławskie

Mścisław

Krzyczeć

Rasna

CAŁOŚ́́

\section{Powiat miński}

Mińsk

Raków

Radoszkowice

Kojdanów

Stołpce

CAŁOŚć

\section{Powiat nowogródzki}

Nieśwież

Lubcz

Mir

Korelicze

CAŁOŚć

Wilno

\section{6}

Źródło: LVIA, SA, 3431; LVIA, SA, 3434III; LVIA, SA, 3430; LVIA, SA, 3417I; LVIA, SA, 3437; LVIA, SA, 3042; LVIA, SA, 3417; AGAD, AR, XV, t. 7, p. 1; Wilnianie. Żywoty siedemnastowieczne, oprac. D. Frick, Warszawa 2008, s. 313.

Analiza przedstawionej tabeli wskazuje na kilka podstawowych cech charakterystycznych sytuacji demograficznej ludności żydowskiej w drugiej połowie XVII w. Mimo że porównanie dwóch rodzajów źródeł: abjuraty podymnego oraz pogłównego niesie ze sobą pewne nieścisłości, jednak chciałabym zwrócić uwagę na kilka podstawowych tendencji.

Pierwsze zagadnienie to skala zniszczeń spowodowanych wojnami połowy XVII w. Choć od zakończenia działań wojennych minęło kilkanaście lat, ich skutki demograficzne były nadal odczuwalne. Regres był widoczny w całym kraju,jednak jak wskazywałam powyżej, nie wszystkie regiony zostały zniszczone w tym samym stopniu. Proces ten można zilustrować kilkoma bardziej szczegółowymi przykładami. Tak więc gmina w Mścisławiu, której liczebność obliczyliśmy w 1650 r. na około 207 osób, w 1676 r. liczyła już tylko 102 osoby, czyli zmniejszyła się o ponad 50\%. Możemy założyć, iż 
skala zniszczenia w województwie połockim była ogromna. W 1677 r. odnotowano tam 114 Żydów, co stanowiło około 20\% przedwojennego stanu. Województwo mścisławskie było jednym z obszarów WKsL najbardziej dotkniętych skutkami wojny. Szacuje się, że ogólne straty ludnościowe na tym obszarze sięgały około $71 \%{ }^{74}$. Wydaje się, że współczynnik ten w wypadku ludności żydowskiej był jeszcze wyższy. Porównanie danych sugeruje także, że obszar ten wolniej niż pozostałe odrabiał straty wojenne. Być może fakt przyłączenia Smoleńszczyzny do Rosji i wprowadzenia na tym obszarze ograniczeń dla Żydów spowodował, że województwo połockie stało się dla nich mniej atrakcyjne.

W mniejszym stopniu skutki wojny, a co za tym idzie, także regres demograficzny, były odczuwalne w zachodnich oraz południowych częściach WKsL. Dla województwa brzeskiego porównanie danych wykazało, iż stan zaludnienia zmniejszył się jedynie o 8\%. Brześć był w mniejszym stopniu niż powiaty wschodnie dotknięty skutkami okupacji wojsk moskiewskich. Wydaje się również, że gminy na tym obszarze odbudowano szybciej. W podobnie niewielkim stopniu skutkami wojny został dotknięty sąsiedni powiat piński. Przypomnijmy, że w 1650 r. w Pińsku mieszkało około 780 Żydów, natomiast w 1677 - 753 osoby, a więc $96 \%$ stanu przedwojennego. Wynik ten wydaje się potwierdzać tezę Nadava, że gmina w Pińsku po wojnach połowy XVII w. została wzmocniona demograficznie $^{75}$. Fakt, że gminy położone w południowo-wschodniej części WKsL poniosły stosunkowo mniejsze straty wskutek działań wojennych, warty jest podkreślenia. Jeszcze w połowie XVII w. obszar ten stanowił teren najważniejszy dla osadnictwa żydowskiego.

Przy analizie powyższej tabeli należy także zwrócić uwagę na fakt szybkiego odbudowania gmin położonych na wschodzie, szczególnie zniszczonych w czasie działań wojsk Aleksego Michajłowicza. W powiecie orszańskim odnotowano aż 13 kahałów, a na całym tym obszarze mieszkało około 1100 Żydów. W tym okresie był to jeden z ważniejszych dla osadnictwa żydowskiego rejonów. Przy czym, jak opisywałam już powyżej, był to zarazem jeden z obszarów najbardziej dotkniętych skutkami wojny, gdzie większość gmin żydowskich przestała w ogóle istnieć. W tym miejscu możemy przypomnieć cytowany powyżej przykład Szkłowa, w którym w 1661 r. mieszkało 2 Żydów, a w abjuracie pogłównego (1676-1677) odnotowano aż 177 osób, co przewyższa znacznie stan liczebności gminy z lat czterdziestych XVII w. Fakt ten wydaje się świadczyć o tym, że większa część mieszkańców Szkłowa została albo uprowadzona, albo uciekała z miasta,jednak po ustą-

\footnotetext{
74 J. Morzy, op. cit., tabela nr 25.

${ }^{75}$ M. Nadav, The Jews of Pinsk, s. 183.
} 
pieniu wojsk moskiewskich wróciła do dawnej gminy. Obok powrotów gmina musiała stać się także celem migracji ludności żydowskiej, gdyż zanotowany tutaj przyrost jest bardzo wysoki. Na temat przyczyn tego zjawiska można tylko spekulować. Być może do miasta przemieścili się Żydzi $z$ terenów zajętych po rozejmie andruszowskim przez Rosję. Prawdopodobnie miasto prywatne, które oferowało Żydom lepsze warunki rozwoju ekonomicznego, było chętnie wybieranym celem migracji ${ }^{76}$. We wcześniejszych badaniach podkreślano również, że miasteczka szybciej niż miasta podnosiły się po zniszczeniach wojennych, co miało bezpośredni wpływ na migracje żydowskie ${ }^{77}$. Charakterystyczne jest, iż w tym samym okresie nie zaobserwowano wzrostu demograficznego wśród ludności chrześcijańskiej miasta $^{78}$.

Znamienne są również dane dla Wilna. W abjuracie zostały zgłoszone jedynie osoby mieszkające na terenach tzw. jurydyki zamkowej oraz jurydyki biskupa wileńskiego. Oczywiście należy przypuszczać, że również w innych częściach miastach mieszkali Żydzi - trudno oszacować, ile było to osób ${ }^{79}$. W porównaniu jednak do pierwszej połowy XVII w., kiedy według danych I. Klauznera mieszkało w Wilnie ponad 2,5 tys. Żydów, ubytek ludności żydowskiej stolicy był znaczny - sięgał około 50\%.

Przedstawione dane z abjurat pogłównego możemy jeszcze uzupełnić informacjami z dwóch innych rodzajów źródeł - to znaczy abjurat podymnego oraz inwentarzy dóbr. Uzupełnienie to da bardziej szczegółowy obraz sytuacji demograficznej Żydów w drugiej połowy XVII w. Szczególnie ciekawe jest porównanie danych z abjurat pogłównego z późniejszymi o kilkanaście lat abjuratami podymnego. Przy analizie tej należy zdawać sobie sprawę z małej dokładności źródeł - szczególnie opisywanej już we wcześniejszych badaniach małej wiarygodności abjuraty podymnego z 1690 r., a także nieścisłości wynikającej z porównania różnego rodzaju dokumentów oraz luk w materiale źródłowym ${ }^{80}$.

W abjuratach pogłównego brakuje kilku ważnych kahałów, np. w województwie nowogródzkim pominięty został Słuck, będący w tym okresie jedną z ważniejszych gmin litewskich. W mieście tym w 1661 r. odnotowano około 475 osób, 22 lata później, w 1683 r., naliczono 700 osób ${ }^{81}$.

\footnotetext{
${ }^{76}$ Por. T. Opas, Sytuacja ludności żydowskiej w miastach szlacheckich województwa lubelskiego w XVIII w., BŻIH 1968, nr 67, s. 5.

77 S. Alexandrowicz, Osadnictwo żydowskie na ziemiach litewsko-białoruskich, s. 59.

${ }^{78}$ M.B. Topolska, op. cit., s. 23.

${ }^{79}$ Wilnianie. Żywoty siedemnastowieczne, s. 313.

${ }^{80}$ A. Rachuba, Wstęp, w: Metryka Litewska. Rejestry podymnego Wielkiego Księstwa Litewskiego. Województwo wileńskie, s.11-22.

${ }^{81}$ AGAD, AR, XXV, sygn. 3831; sygn. 3834/1, Inwentarze Słucka z lat 1661 oraz 1683.
} 
W Nowogródku w 1690 r., jak dowiadujemy się z abjuraty podymnego, było 29 dymów żydowskich ${ }^{82}$. Z tego samego źródła czerpiemy dane dotyczące Nieświeża (32 dymy) oraz Korelicz (12 dymów). Ten ostatni przykład pokazuje, że gmina korelicka przez niecałe 20 lat od czasu składania abjurat pogłównego bardzo się rozwinęła, porównanie danych pokazało trzykrotny wzrost liczby mieszkańców. Analogiczną tendencję widzimy także w przypadku miejscowości w powiecie słonimskim. Na tym terenie największe gminy znajdowały się w sapieżyńskiej Różanej (38 dymów) oraz w Słonimiu (25 dymów). Zdecydowanie mniejsze były kahały w sapieżyńskim Kosowie (10 dymów) oraz w Byteniu (8 dymów) ${ }^{83}$. W obydwu wypadkach skala wzrostu jest bardzo wysoka, być może wynika to z porównania dwóch różnych rodzajów źródeł, na tym etapie badań nie jestem w stanie jednak zweryfikować tych wyników.

Korzystając również z abjurat podymnego, można scharakteryzować sytuację demograficzną niektórych gmin województwa trockiego ${ }^{84}$. W Grodnie zgłoszono 25 domów ${ }^{85}$. Dodatkowo dysponujemy inwentarzem ekonomii grodzieńskiej z 1680 r. Wśród miasteczek ekonomicznych największym skupiskiem żydowskim był Nowy Dwór (29 gospodarzy), nieco mniejsze skupiska żydowskie znajdowały się w Odelsku (19 gospodarzy), Krynkach i Lipsku (po 11 gospodarzy) oraz w Łunie i Jeziorze (po 10 gospodarzy) $)^{86}$.

Dane dotyczące województwa wileńskiego czerpiemy również z rejestrów podymnego, przy czym dysponujemy informacjami tylko o Wilnie. W dzielnicy żydowskiej odnotowano 216 gospodarzy wraz z sąsiadami (czyli chodzi tutaj o głowy rodziny) mieszkających w siedmiu wielkich kamienicach oraz 14 małych. Natomiast 102 gospodarzy odnotowano w innych obszarach miasta ${ }^{87}$.

Najmniej danych udało się zgromadzić w stosunku do kahałów położonych w północnych powiatach WKsL. Na przykład w radziwiłłowskiej (birżańskiej) Bielicy w powiecie lidzkim odnotowano w 1696 r. 38 gospodarzy żydowskich, czyli w mieście mieszkało zatem pewnie około

${ }^{82}$ Metryka Litewska. Rejestry podymnego Wielkiego Księstwa Litewskiego. Województwo nowogródzkie 1690 r., oprac. H. Lulewicz, A. Rachuba, Warszawa 2002, s. 106.

${ }^{83}$ Ibidem, s. 152.

${ }^{84}$ Metryka Litewska. Rejestry podymnego Wielkiego Księstwa Litewskiego. Województwo trockie 1690 r., oprac. H. Lulewicz, Warszawa 2000, s. 123.

${ }^{85}$ LVIA, SA, 3459, k. 37, Abjurata podymnego województwa trockiego.

${ }^{86}$ LVIA, SA, f. 110, ap. 1, s. 3, „Inwentarz ekonomii grodzieńskiej rewizji anno 1680", k. 41-43.

${ }^{87}$ Metryka Litewska. Rejestry podymnego Wielkiego Księstwa Litewskiego. Województwo wileńskie 1690 r., s. 66. 
190 osób $^{88}$. Nieco bardziej liczni byli Żydzi w należących do tej samej rodziny Birżach. W 1695 r. odnotowano tam 49 gospodarstw żydowskich, zatem w mieście mieszkało około 250 osób ${ }^{89}$.

Zgromadzone materiały źródłowe niestety nie pozwalają na próbę oszacowania ogólnej liczby ludności żydowskiej w WKsL w drugiej połowie XVII w. Z tego też powodu niemożliwe jest ani określenie stopnia przyrostu, ani całościowe oszacowanie strat demograficznych związanych z wojnami połowy XVII w.

Podsumowując, można stwierdzić, że pierwsza połowa XVII w. to okres powolnego wzrostu demograficznego diaspory litewskiej - jak udało się stwierdzić, w połowie wieku żyło na terenie WKsL około 20 tys. Żydów. Rozwój ten został zahamowany poprzez wojny połowy XVII w., których znaczące skutki demograficzne poniosła diaspora litewska. Choć, jak należy podkreślić, nie wszystkie gminy zostały zniszczone w tym samym stopniu, niektóre zostały wzmocnione demograficznie wskutek wzmożonej migracji. Na wielu obszarach WKsL skutki zniszczeń wojennych były odczuwalne jeszcze w drugiej połowie XVII w., jednak zjawisko to było nierównomierne w całym państwie. Wzrost demograficzny ludności żydowskiej był jednak znacznie szybszy niż ludności chrześcijańskiej, straty demograficzne ulegały szybszemu zniwelowaniu. Zjawisko to mogło mieć kilka przyczyn. Kluczowy dla rozpatrywania rozwoju demograficznego ludności żydowskiej jest fakt, że w trakcie działań wojennych połowy XVII w. najmniej ucierpiały obszary największej koncentracji osadnictwa żydowskiego. Następnie należy podkreślić, iż w ostatnich dekadach XVII w. rozpoczęło się zjawisko stałego wzrostu demograficznego ludności żydowskiej. Czynnikiem stymulującym ten proces była zapewne polityka władców, dająca Żydom wiele nowych możliwości działalności gospodarczej ${ }^{90}$. Należy również pamiętać o względnie wysokim przyroście naturalnym notowanym w społeczności żydowskiej. Otwarte pozostaje pytanie o znaczenie migracji zewnętrznej ${ }^{91}$.

${ }^{88}$ AGAD, AR, XXV, sygn. 188, „Inwentarz Bielicy i folwarku Zblan zostawiony przy [--] dla wybierania prowentów spisany”, 10 XI 1696.

${ }^{89}$ AGAD, AR, XXV, sygn. 235, „Inwentarz miasta Birż w powiecie upitskim leżących", październik 1695.

${ }^{90}$ Na temat polityki władców w WKsL por: M. Cieśla, „Żydzi w Wielkim Księstwie Litewskim 1632-1764. Sytuacja prawna. Demografia. Działalność gospodarcza”, Warszawa 2010, mps pracy doktorskiej, s. 32-136.

${ }^{91}$ Potwierdzeniem znaczenia migracji zewnętrznej są uchwały Waadu litewskiego z lat siedemdziesiątych XVII w. wprowadzające restrykcje w stosunku do wszystkich obcych przebywających na terenie gmin litewskich, I. Susis, op. cit., s. 31. 


\section{The Number of Jews in the Grand Duchy of Lithuania during the Seventeenth Century}

The basic sources of this attempt to determine the number of Jews in the Grand Duchy of Lithuania during the seventeenth century include treasury documents up to now used only on the margins of studies about the demography of the Jews, i.e. predominantly registers of the podymne (hearth) and the pogtówne (poll) taxes and, as auxiliary material, protocols of the sessions of the Lithuanian Waad (Jewish Sejm). Such sources made it feasible to determine that in 1650 the Grand Duchy was inhabited by about 18900 Jews, i.e. $0,51 \%$ of the total population and $3,5 \%$ of the town dwellers. The unsatisfactory state of the preservation of treasury sources from the second half of the seventeenth century means that it is impossible to even propose an approximate number of the Jews. A comparison of fragmentary data makes it feasible to draw conclusions concerning trends of the demographic growth of the Jewish population and to ascertain that in certain regions the impact of losses associated with wars waged in the mid-seventeenth century was still felt in the second half of the seventeenth century. This phenomenon, however, was not identical across the entire state. It should be emphasised that not all the kahals were destroyed to the same degree; moreover, some grew due to increased migration. The demographic growth of the Jewish population was much speedier than that of the Christian population, and demographic losses were eliminated more rapidly. The reasons for this state of affairs include: 1) that fact that the smallest losses during the armed conflicts of the mid-seventeenth century were suffered by areas with the greatest concentrations of the Jewish population, 2) favourable conditions for the economic progress of the Jewish population, and 3) a relatively high birth rate.

Translated by Aleksandra Rodzińska-Chojnowska 